\title{
ELECTROPHORETIC STUDIES OF THE PLASMA AND SERUM PROTEINS IN SICKLE CELL ANEMIA ${ }^{1}$
}

\author{
BY RICHARD L. FENICHEL, JANET WATSON, AND FREDERICK EIRICH
}

\begin{abstract}
Grom Brooklyn Polytechnic Institute and the Department of Medicine, State University of
\end{abstract} New York, College of Medicine, Brooklyn, N.Y.)

(Submitted for publication July 19, 1950; accepted, September 26, 1950)

The underlying pathological defect of sickle cell anemia has long been known to be within the erythrocyte itself (1). Although it has been well demonstrated (2) that deprivation of oxygen results in almost instantaneous transformation of the discoid erythrocyte into its bizarre sickled shape, the exact dynamic mechanism has yet to be elucidated. In our study of the physiochemical properties of the sickle cell (to be reported later), we included also the electrophoretic study of the plasma and serum. This seemed important because of the possible additional effect the serum might have upon the sickling property of the red cell and because of possible pathological alteration of the serum secondary to the general disease process of sickle cell anemia. Electrophoretic analysis of the plasma of only one patient with sickle cell anemia has been reported (3).

\section{MATERIAL AND METHODS}

Blood samples were obtained at intervals from 15 patients with active sickle cell disease under medical care at Kings County Hospital, and from a healthy negro with

1 This work was supported by a grant from the Commonwealth Fund. the sickle cell trait. All patients with sickle cell anemia had the disease in a severe form requiring frequent hospital admissions for crises. Electrophoretic studies were performed by the standard technique, as reported in detail previously (4). The buffer was sodium diethylbarbiturate (veronal) of $\mathrm{pH} 8.6$ and ionic strength of 0.1 . Total proteins were determined by a standard $\mathrm{Kjeldahl}$ analysis, and from these data the absolute values of the individual protein fractions were computed. The normal control electrophoretic values used were from a series of 80 cases reported elsewhere (4).

\section{RESULTS}

The electrophoretic data on the serum of 12 cases of sickle cell anemia are shown in Table I; similar data on the plasma of 14 cases are shown in Table II. Case numbers of individual cases correspond in the two tables, so that the plasma and serum values of the same patient can be directly compared. In Tables III and IV are shown relative and absolute values respectively of the protein fractions of the sickle cell anemia cases compared with normal values. It is to be noted that there appears to be no consistent difference between plasma and serum values. However, there were certain discrepancies, such as those in the serum and plasma values of the beta and

TABLE I

Electrophoretic values of the serum proteins of cases of sickle cell anemia

\begin{tabular}{|c|c|c|c|c|c|c|c|c|c|c|c|c|c|}
\hline Case No. & $\frac{\text { Age }}{\text { yrs }}$ & Hgb. & \multicolumn{2}{|c|}{ Alb. } & \multicolumn{2}{|c|}{ Alpha1 } & \multicolumn{2}{|c|}{ Alphaz } & \multicolumn{2}{|c|}{ Beta } & \multicolumn{2}{|c|}{ Gamma } & $\underset{\text { Ratio }}{\text { A/G }}$ \\
\hline $\begin{array}{l}1 \\
2 \\
3 \\
4 \\
5 \\
6-a \\
7 \\
9 \\
10 \\
11 \\
14 \\
15\end{array}$ & $\begin{array}{c}y r s . \\
20 \\
20 \\
18 \\
19 \\
11 \\
33 \\
20 \\
7 \\
25 \\
49 \\
24 \\
32\end{array}$ & $\begin{array}{r}\text { gm. \% } \\
6.3 \\
6.2 \\
7.8 \\
6.7 \\
8.1 \\
8.1 \\
11.4 \\
7.6 \\
9.4 \\
13.0 \\
8.5 \\
7.0\end{array}$ & $\begin{array}{c}\% \\
50.4 \\
47.4 \\
47.0 \\
39.4 \\
56.0 \\
41.5 \\
42.4 \\
58.5 \\
55.0 \\
46.2 \\
49.2 \\
45.0\end{array}$ & $\begin{array}{c}\text { gm. \% } \\
3.58 \\
3.24 \\
3.22 \\
3.15 \\
\\
3.37 \\
3.13 \\
4.03 \\
3.79 \\
3.23 \\
4.33 \\
3.33\end{array}$ & $\begin{array}{l}\% \\
6.30 \\
7.20 \\
6.00 \\
5.40 \\
2.7 \\
5.0 \\
3.9 \\
7.25 \\
8.30 \\
4.00 \\
5.20 \\
6.54\end{array}$ & $\begin{array}{c}\text { gm. \% } \\
0.45 \\
0.49 \\
0.41 \\
0.43 \\
0.41 \\
0.29 \\
0.50 \\
0.57 \\
0.28 \\
0.46 \\
0.48\end{array}$ & $\begin{array}{l}\% \\
9.4 \\
9.9 \\
7.0 \\
6.3 \\
7.7 \\
6.3 \\
3.9 \\
7.5 \\
8.3 \\
6.3 \\
6.3 \\
6.1\end{array}$ & $\begin{array}{c}\text { gm. \% } \\
0.65 \\
0.67 \\
0.48 \\
0.50 \\
0.51 \\
0.29 \\
0.52 \\
0.57 \\
0.44 \\
0.55 \\
0.45\end{array}$ & $\begin{array}{r}\% \\
11.5 \\
12.9 \\
11.5 \\
12.6 \\
11.5 \\
15.6 \\
8.6 \\
13.0 \\
9.7 \\
15.6 \\
13.0 \\
12.6\end{array}$ & $\begin{array}{c}\text { gm. \% } \\
0.82 \\
0.88 \\
0.79 \\
1.00 \\
1.23 \\
0.63 \\
0.90 \\
0.67 \\
1.09 \\
1.14 \\
0.93\end{array}$ & $\begin{array}{c}\% \\
22.4 \\
22.6 \\
29.0 \\
36.3 \\
22.0 \\
31.8 \\
40.8 \\
13.7 \\
18.5 \\
28.0 \\
26.4 \\
30.0\end{array}$ & $\begin{array}{c}\text { gm. \% } \\
1.59 \\
1.53 \\
2.00 \\
2.96 \\
\\
2.59 \\
3.01 \\
0.95 \\
1.28 \\
1.96 \\
2.32 \\
2.22\end{array}$ & $\begin{array}{l}1.0 \\
0.9 \\
0.9 \\
0.7 \\
1.3 \\
0.7 \\
0.8 \\
1.4 \\
1.2 \\
0.9 \\
1.0 \\
0.8\end{array}$ \\
\hline
\end{tabular}

Cases No. 1-6 in crisis

Cases No. 7-15 not in crisis 
SERUM PROTEINS IN SICKLE CELL ANEMIA

TABLE II

Electrophoretic values of the plasma proteins of cases of sickle cell anemia

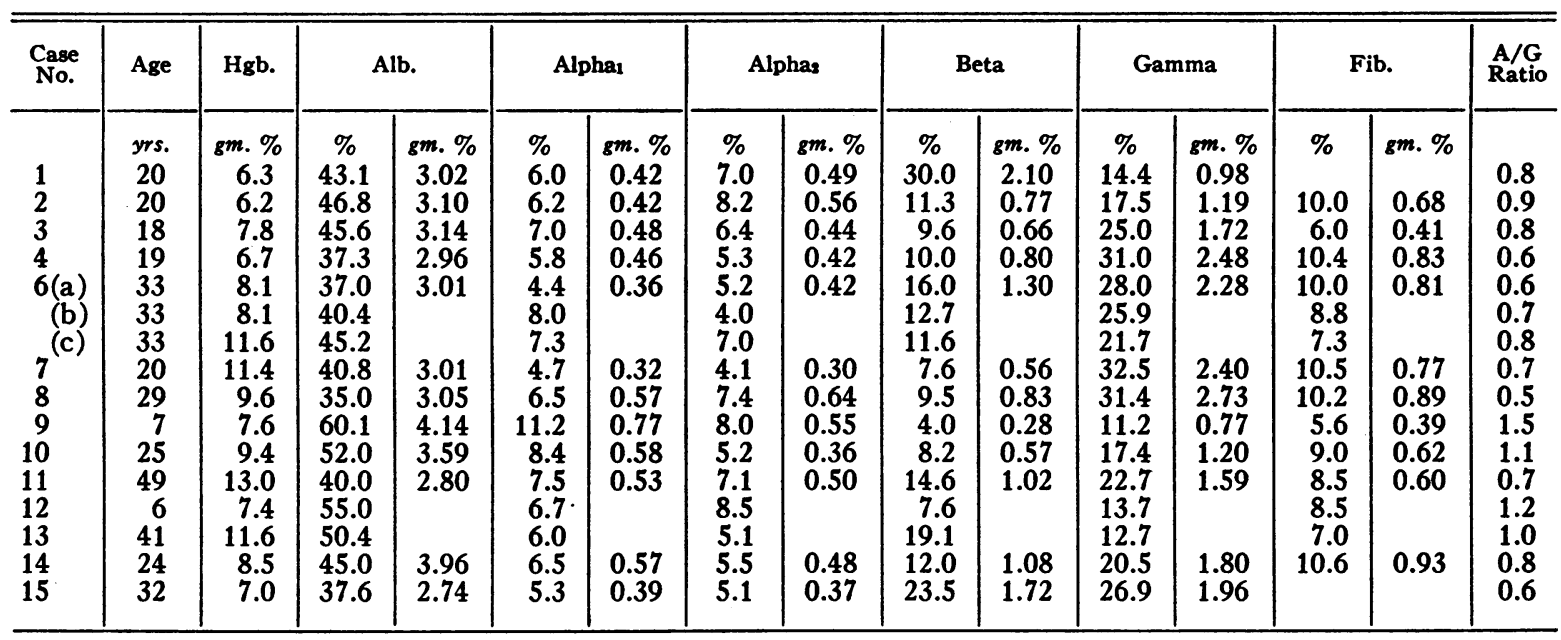

Cases No 1-6(a) in crisis

Cases No. 6(b)-15 not in crisis

gamma globulins in case No. 1 . It is possible that some of these may be due to difficulties in resolution of the fibrinogen peak because of overlapping of beta and/or gamma globulins.

The albumin fraction was found to be below the normal of $4.0 \mathrm{gm}$. per $100 \mathrm{ml}$. in 13 of the 15 cases. The mean values were $3.20 \mathrm{gm}$. per $100 \mathrm{ml}$. for plasma and 3.43 for serum. The values for gamma globulin were elevated above $1.2 \mathrm{gm}$. per $100 \mathrm{ml}$. in 12 of the 15 cases. The mean value for serum gamma globulin was 1.88 , thus being well above the normal value of $1.06 \mathrm{gm}$. per $100 \mathrm{ml}$. Only three cases were found to have elevated beta globulins, and none had significant abnormalities of the alpha globulins. Because of the low albumin and elevated gamma globulin there was a reversal of the $A / G$ ratio to 1.0 or less in 12 of the 15 cases. The mean was 0.87 compared with the normal of 1.28 .

Since our normal control data were obtained from the study of sera, normal fibrinogen values for comparison are quoted from others. Ham and Curtis (5) found normal fibrinogen values of 0.19 to $0.33 \mathrm{gm}$. per $100 \mathrm{ml}$. with a mean of 0.25 by a quantitative chemical technique. Cohn and his associates (6), using electrophoretic methods, considered the normal fibrinogen value to be $0.43 \mathrm{gm}$. per $100 \mathrm{ml}$. Dole $(7 a)$, using similar methods, found fibrinogen in normal males to be $0.34 \mathrm{gm}$. per $100 \mathrm{ml}$. with a standard devia- tion of 0.059. Fibrinogen was determined in ten of our cases and found to be elevated to $0.60 \mathrm{gm}$. per $100 \mathrm{ml}$. or more in eight, with a value of 0.41 and 0.39 in the other two cases. The mean value was $0.67 \mathrm{gm}$. per $100 \mathrm{ml}$, or approximately twice normal.

About one-third of our cases were studied during acute crisis. The abnormalities of the proteins found did not seem to differ significantly

TABLE III

Electrophoretic values (relative) of blood proteins of sickle cell anemia cases and of normals

\begin{tabular}{lr|c|c|c|c|c|c|c}
\hline \hline \multicolumn{1}{|c|}{ Protein, \% } & Alb. & Alpha & Alpha & Beta & Gamma & $\begin{array}{r}\text { Fibrin- } \\
\text { ogen }\end{array}$ & $\begin{array}{c}\text { A/G } \\
\text { Ratio }\end{array}$ \\
\hline Mean (a) & 45.8 & 6.7 & 6.8 & 12.8 & 21.5 & 8.6 & .87 \\
Mean (b) & 47.8 & 5.8 & 7.1 & 12.2 & 26.7 & & .93 \\
Mean (c) & 56.0 & 7.26 & 8.99 & 13.2 & 14.8 & & 1.28 \\
\hline Median (a) & 44.1 & 6.6 & 6.6 & 11.4 & 19.5 & 8.8 & .81 \\
Median (b) & 46.6 & 6.2 & 6.4 & 12.3 & 27.2 & & .90 \\
Median (c) & 55.8 & 7.03 & 8.91 & 13.1 & 14.9 & & 1.30 \\
\hline Mode (a) & 40.7 & 6.4 & 6.2 & 8.6 & 15.5 & 9.2 & .69 \\
Mode (b) & 44.2 & 7.0 & 5.0 & 12.5 & 28.2 & & .84 \\
Mode (c) & 55.3 & 6.57 & 8.75 & 12.9 & 15.0 & & 1.34 \\
\hline S. D. (a) & 7.54 & 1.56 & 2.24 & 5.34 & 7.78 & 1.6 & .32 \\
S. D. (b) & 6.23 & 1.39 & 1.94 & 1.84 & 7.69 & & .26 \\
S. D. (c) & 3.18 & 1.42 & 1.97 & 2.38 & 2.78 & & .17 \\
\hline S. E. (a) & 1.73 & .35 & .51 & 1.22 & 1.78 & .42 & .07 \\
S. E. (b) & 1.60 & .36 & .50 & .47 & 1.98 & & .07 \\
S. E. (c) & .36 & .16 & .22 & .27 & .31 & & .02 \\
\hline
\end{tabular}

(a) Sickle cell anemia plasma

(b) Sickle cell anemia serum

(c) Normal serum 
TABLE IV

Electrophoretic values (absolute) of blood proteins of sickle cell anemia cases and of normals

\begin{tabular}{ll|c|c|c|c|c|c|c}
\hline \hline \multicolumn{1}{l|}{ Protein, gm. \% } & Alb. & Alpha & Alpha & Beta & Gamma & $\begin{array}{r}\text { Fibrin- } \\
\text { ogen }\end{array}$ & $\begin{array}{c}\text { A/G } \\
\text { Ratio }\end{array}$ \\
\hline Mean (a) & 3.20 & .55 & .49 & .93 & 1.79 & .67 & .84 \\
Mean (b) & 3.43 & .44 & .51 & .84 & 1.88 & & .87 \\
Mean (c) & 4.09 & .52 & .65 & .96 & 1.06 & & 1.28 \\
\hline Median (a) & 3.65 & .49 & .49 & .82 & 1.76 & .68 & .76 \\
Median (b) & 3.33 & .45 & .50 & .88 & 2.00 & & .90 \\
Median (c) & 4.09 & .56 & .68 & 1.02 & 1.12 & & 1.30 \\
\hline Mode (a) & 4.55 & .37 & .48 & .59 & 1.7 & .70 & .59 \\
Mode (b) & 3.13 & .47 & .48 & .96 & 2.24 & & .96 \\
Mode (c) & 4.09 & .64 & .74 & 1.14 & 1.24 & & 1.34 \\
\hline S. D. (a) & .45 & .13 & .52 & .41 & .76 & .44 & .31 \\
S. D. (b) & .56 & .37 & .32 & .36 & .78 & & .25 \\
S. D. (c) & .37 & .11 & .18 & .21 & .21 & & .17 \\
\hline S. E. (a) & .10 & .03 & .09 & .09 & .18 & .10 & .07 \\
S. E. (b) & .14 & .09 & .09 & .09 & .20 & & .06 \\
S. E. (c) & .04 & .01 & .02 & .02 & .02 & & .02 \\
\hline
\end{tabular}

(a) Sickle cell anemia plasma

(b) Sickle cell anemia serum

(c) Normal serum

from those found in the cases not in crisis. In one case (No. 6), three samples of blood ( $a, b$, and c) were taken at monthly intervals, the first having been taken when the patient was in crisis and the succeeding two when the patient was relatively symptom free. There appeared to be no real differences in the three determinations. However, more patients should be followed in and out of crisis in order to determine definitely the presence of any significant fluctuations in the protein fraction values.

There were only three patients studied under the age of 18; these were aged one and a half, six, and seven years (cases Nos. 5, 12 and 9 respectively). These three cases had the fewest abnormalities. All three had normal albumin and alpha and beta globulins. Case No. 9 had a fibrinogen value at

TABLE $V$

Electrophoretic values of the plasma proteins of a case of sickle cell trait (S.C.T.)

\begin{tabular}{l|c|c|c|c|c}
\hline \hline \multicolumn{1}{c|}{ Source } & Alb. & Alpha1 & Alphaz & Beta & Gamma \\
\hline S.C.T. serum, \% & 59.7 & 6.5 & 6.5 & 11.5 & 16.0 \\
Normal serum, \% & 56.0 & 7.26 & 8.99 & 13.2 & 14.8 \\
S.C.T. serum, gm. \% & 3.9 & 0.43 & 0.43 & 0.75 & 1.05 \\
Normal serum, gm. \% & 4.09 & 0.52 & 0.65 & 0.96 & 1.06 \\
S.C.T. plasma, \% & 64.3 & 8.2 & 10.2 & 10.2 & 7.0 \\
S.C.T. plasma, gm. \% & 4.24 & 0.54 & 0.66 & 0.66 & 0.46 \\
\hline
\end{tabular}

S.C.T.: A/G Ratio 1.50; Normal, 1.28. the upper limit of normal, and case No. 12 had an elevated one. Only one case (No. 5) had an elevated gamma globulin. Knapp and Routh $(7 b)$ in electrophoretic studies of plasma proteins in 54 normal children found no differences from the adult with the exception of the gamma globulin which was $3.3 \%$ at six to 46 weeks, $7.2 \%$ at one to four years, and $9.7 \%$ at five to 11 years when it reached the adult mean of $9.6 \%$. Hence case No. 5, aged one and a half years, normally might have had a low gamma globulin, but it actually was increased above the adult level.

Electrophoretic data on a normal negro with the sickle cell trait is presented in Table V. It is evident that the values fell within normal limits. Unfortunately, we have studied no other cases with the trait, since we were primarily interested in those with sickle cell disease.

\section{DISCUSSION}

Summarizing the results, electrophoretic studies of the proteins of 15 patients with sickle cell anemia showed hypoalbuminemia in 13 , elevated gamma globulin in 12 , elevated beta globulin in three, and reversal of the $\mathrm{A} / \mathrm{G}$ ratio in 12 cases. Increased fibrinogen was found in eight of the ten cases in which it was determined. It is now generally agreed that abnormal electrophoretic patterns are not specific for definite disease processes, with the exception of some cases of multiple myeloma and lipoid nephrosis (8-10). The abnormalities described here are relatively common in a variety of diseases, but are most consistently present in diseases associated with hepatic dysfunction such as acute hepatitis $(11,12)$, cirrhosis of the liver (13-15), and infectious mononucleosis (16). There has been good correlation in these diseases with a positive cephalin flocculation (17), and it is interesting that this test was positive 3 or 4 plus in the majority of our patients on whom the test was done. However, a low albumin and high gamma globulin and fibrinogen have been reported in a great variety of other diseases (8, $9,18)$ such as nephritis, multiple myeloma, kala azar, lymphogranuloma venereum, advanced tuberculosis, sarcoidosis, leprosy, active malaria, rheumatic fever, rheumatoid arthritis, lupus erythematosis, infectious diseases, and cancer associated with tissue breakdown. Since there is no obvious common denominator in these diseases, additional 
general pathological changes must also be considered as possible factors in the production of the protein abnormalities in sickle cell anemia.

In sickle cell anemia there is apparently almost constant tissue breakdown as a result of circulatory disturbances due to the sickling which takes place in the capillaries in all the organs of the body (19). As the disease progresses, despite reparative efforts, some of the organs may become more permanently damaged, resulting sometimes in such complications as chronic nephritis, atrophy of the spleen, or liver damage (20). The livers in the majority of cases are enlarged. Pathologically (21) the liver often shows marked congestion, swelling of the Kupffer cells with erythrophagocytosis, and hemosiderosis of the liver cells. With the chronic disease, most of the patients suffer to a certain extent from malnutrition, which is a factor favoring low albumin. The influence of time upon the progression of the disease may account for the lesser degree of abnormalities of the plasma proteins in our three very young patients. Since, in the sickle cell trait, the cells do not assume the sickled shape within the body (1), thus not producing any pathological changes, one would not expect to find abnormalities in the plasma proteins. Our one case with the trait showed normal plasma and serum proteins.

Because of the absence of protein abnormalities peculiar to sickle cell anemia itself, there is no reason to suppose that there is anything specifically at fault with the serum which might have an effect upon sickling. It has been previously demonstrated by sickle cell washings as being very likely that the intrinsic defect in the disease lies within the red blood cell and not within the plasma (1). Furthermore, Pauling and his colleagues (22), by means of careful electrophoretic technic, have recently shown that the sickle cell hemoglobin itself is abnormal. Also, the Coombs test (23) fails to show the presence of a serum component attached to the red cell. We have at present, therefore, no indication of any specific interaction between plasma and erythrocytes in sickling, although we cannot consider the matter entirely closed as yet. However, we believe that the changes in the proteins found in our cases are secondary to the general disease processes, especially in the liver, caused by the sickled cell.

\section{CONCLUSIONS}

1. Electrophoretic studies were made of the serum and plasma in 15 cases of sickle cell anemia and in one case of sickle cell trait.

2. Protein partition values were normal in the one case of sickle cell trait.

3. In the 15 cases of sickle cell anemia, 13 had a decreased albumin; 12 , elevated gamma globulin ; three, elevated beta globulin; and 12, a reversal of the $A / G$ ratio. The fibrinogen was elevated in eight of the ten cases in which it was determined.

4. It is thought that these abnormalities are nonspecific and that they may represent the reaction to the tissue breakdown caused by the sickling process in various organs, particularly within the liver.

\section{BIBLIOGRAPHY}

1. Huck, J. G., Sickle cell anemia. Bull. Johns Hopkins Hosp., 1923, 34, 335.

2. Sherman, I. J., The sickling phenomenon, with special reference to the differentiation of sickle cell anemia from the sickle cell trait. Bull. Johns Hopkins Hosp., 1940, 67, 309.

3. Murphy, R. C., Jr., and Shapiro, S., The pathology of sickle cell disease. Ann. Int. Med., 1945, 23, 376.

4. Reiner, M., Fenichel, R. L., and Stern, K. G., Electrophoretic studies on the protein distribution in normal human serum. Acta haemat., 1950, 3, 202.

5. Ham, T. H., and Curtis, F. C., Plasma fibrinogen response in man; influence of nutritional state, induced hyperpyrexia, infectious disease and liver damage. Medicine, 1938, 17, 413.

6. Cohn, E. J., Oncley, J. L., Strong, L. E., Hughes, W. L., Jr., and Armstrong, S. H., Jr., Chemical, clinical and immunological studies on the products of human plasma fractionation. I. The characterization of the protein fractions of human plasma. J. Clin. Invest., 1944, 23, 417.

7a. Dole, V. P., The electrophoretic patterns of normal plasma. J. Clin. Invest., 1944, 23, 708.

b. Knapp, E. L., and Routh, J. I., Electrophoretic studies of plasma proteins in normal children. Pediatrics, 1949, 4, 508.

8. Gutman, A. B., Plasma proteins in disease, in Advances in Protein Chemistry, edited by Ansen, M. L., and Edsall, J. T. Academic Press, New York, 1948, Vol. 4, 155.

9. Stern, K. G., and Reiner. M., Electrophoresis in medicine. Yale J. Biol. \& Med., 1946, 19, 67.

10. Bongiovanni, A. M., and Wolman, I. J., Plasma protein fractionation in pediatrics. Am. J. M. Sc., 1949, 218, 700. 
11. Ricketts, W. E., and Sterling, K., Electrophoretic studies of the serum proteins in virus hepatitis. J. Clin. Invest., 1949, 28, 1477.

12. Rafsky, H. A., Weingarten, M., Krieger, C. I., Stern, K. G., and Newman, B., Electrophoretic studies in liver disease. Gastroenterology, 1950, 14, 29.

13. Gray, S. J., and Barron, E. S. G., The electrophoretic analysis of the serum proteins in diseases of the liver. J. Clin. Invest., 1943, 22, 191.

14. Ricketts, W. E., Sterling, K., Kirsner, J. B., and Palmer, W. L., Electrophoretic studies of the serum proteins in portal cirrhosis. Gastroenterology, 1949, 13, 205.

15. Sterling, K., and Ricketts, W. E., Electrophoretic studies of the serum proteins in biliary cirrhosis. J. Clin. Invest., 1949, 28, 1469.

16. Sterling, $K$., The serum proteins in infectious mononucleosis: electrophoretic studies. J. Clin. Invest., 1949, 28, 1057.

17. Moore, D. B., Pierson, P. S., Hanger, F. M., and Moore, D. H., Mechanism of the positive cephalin- cholesterol flocculation reaction in hepatitis. J. Clin. Invest., 1945, 24, 292.

18. Longsworth, L. G., Shedlovsky, T., and MacInness, D. A., Electrophoretic patterns of normal and pathological human blood serum and plasma. J. Exper. Med., 1939, 70, 399.

19. Kimmelstiel, P., Vascular occlusion and ischemic infarction in sickle cell disease. Am. J. M. Sc., 1948, 216, 11.

20. Wintrobe, M. M., Clinical Hematology. Lea \& Febiger, Philadelphia, 1946.

21. Stasney, J., Erythrophagocytosis and hemosiderosis in the liver and spleen in sickle cell disease. Am. J. Path., 1943, 19, 225.

22. Pauling, L., Itano, H. A., Singer, S. J., and Wells, I. C., Sickle cell anemia, a molecular disease. Science, 1949, 110, 543.

23. Singer K., and Motulsky, A. G., The developing (Coombs) test in spherocytic hemolytic anemias; its significance for the pathophysiology of spherocytosis and splenic hemolysis. J. Lab. \& Clin. Med., 1949, 34, 768. 